\title{
SISTEM PENDUKUNG KEPUTUSAN TENDER PROYEK MENGGUNAKAN METODE BENEFIT COST RATIO
}

\author{
Siti Hardiyanti Rukmana ${ }^{1}$, Much Aziz Muslim² \\ 1,2Jurusan IImu Komputer, Fakultas Matematika dan IImu \\ Pengetahuan Alam, Universitas Negeri Semarang \\ Semarang, Indonesia
}

e-mail: sitihardiyantirukmana2@gmail.com, a212muslim@yahoo.com

\begin{abstract}
Abstrak
Proses pengadaan barang menjadi salah satu aspek penting bagi PT. PLN (Persero) untuk menjalankan perusahaannya. Salah satu cara untuk memenuhi kebutuhan tersebut yaitu melalui tender proyek. Proses tender bertujuan untuk mendapatkan material bermutu dengan harga yang termurah yang memenuhi kriteria efisiensi PT. PLN (Persero). Dalam rangka untuk mempermudah proses tender tersebut diperlukan suatu sistem pendukung keputusan. Metode yang digunakan pada sistem ini yaitu Benefit Cost Ratio (BCR). Masukan dalam aplikasi ini adalah dokumen tender dan harga penawaran dari peserta tender dengan kelengkapan dokumen-dokumen tender yang sudah divalidasi oleh peserta tender kemudian akan diseleksi oleh panitia tender dengan melakukan penilaian dan validasi pemenang. Keluaran dari proses ini adalah pemenang tender proyek berdasarkan perhitungan Benefit Cost Ratio (BCR). Dengan demikian, metode Benefit Cost Ratio (BCR) dapat digunakan sebagai sistem pendukung keputusan untuk menentukan pemenang tender proyek.
\end{abstract}

Kata kunci: Sistem pendukung keputusan, Tender proyek, BCR

\begin{abstract}
The procurement process became one of the important aspects for PT. PLN (Persero) to operate the company. One way to meet these needs is through the project tender. The tender process aims to get high-grade materials with the lowest prices that meet the criteria of efficiency PT. PLN (Persero). In order to simplify the bidding process required a decision support system. The method used in this system is Benefit Cost Ratio (BCR). Input in this application are the documents and the tender offer price from bidders with complete tender documents that have been validated by prospective bidders and then selected by the tender committee to make an assessment and validation winner. The output of this process is the winner of the tender project based on calculations Benefit Cost Ratio (BCR). Therefore, the method Benefit Cost Ratio (BCR) can be used as a decision support system to determine the winner of the project tender.
\end{abstract}

Keywords: Decision support system, Tender project, BCR 


\section{PENDAHULUAN}

PT. PLN (Persero) merupakan salah satu perusahaan Badan Usaha Milik Negara (BUMN) yang bertugas untuk melaksanakan usaha penyediaan tenaga listrik. APP Semarang merupakan salah satu unit pelaksana di wilayah PT. PLN (Persero) P3B Jawa Bali yang bertanggungjawab mengelola operasi dan pemeliharaan instalasi tenaga listrik dengan wilayah Semarang sampai dengan Cepu. Proses pengadaan barang menjadi salah satu aspek penting bagi PT. PLN (Persero) untuk menjalankan perusahaannya. Material yang dibutuhkan PLN dalam hal ini seperti mesin diesel untuk pembangkit listrik, radiator mesin, kabel listrik, dan sebagainya. Salah satu cara untuk memenuhi kebutuhan material tersebut yaitu melalui tender proyek. Tender proyek bertujuan untuk mendapatkan material bermutu dengan harga yang termurah yang memenuhi kriteria efisiensi PT. PLN (Persero).

Proses evaluasi tender yang dilakukan secara konvensional akan menimbulkan adanya persekongkolan tender dimana pelaku usaha melakukan kerjasama dengan pelaku usaha lain untuk menguasai pasar dengan cara mengatur dan menentukan pemenang tender sehingga dapat mengakibatkan persaingan yang tidak sehat. Oleh karena itu, diperlukan suatu sistem pendukung keputusan untuk meminimalisir terjadinya persekongkolan tender dalam menentukan pemenang tender.

Sistem adalah sekelompok elemenelemen yang terintegrasi dengan tujuan yang sama untuk mencapai tujuan. (Yakub, 2012)

Sistem pendukung keputusan merupakan sistem informasi interaktif yang menyediakan informasi, pemodelan dan manipulasi data. Sistem itu digunakan untuk membantu pengambilan keputusan dalam situasi yang semiterstruktur dan situasi tidak terstruktur, dimana tak seorang pun tahu secara pasti bagaimana keputusan seharusnya dibuat. (Kusrini, 2007)

Metode Benefit Cost Ratio (BCR) merupakan metode yang digunakan untuk mengetahui besaran keuntungan/ kerugian serta kelayakan suatu proyek. Metode BCR ini memberikan penekanan terhadap nilai perbandingan antara aspek manfaat (benefit) yang akan diperoleh dengan aspek biaya dan kerugian yang akan ditanggung (cost). (Giatman, 2006)

Sistem pendukung keputusan tender proyek ini dapat digunakan sebagai "second opinion" atau "information sources" yang dapat dipakai sebagai bahan pertimbangan bagi PT. PLN (Persero) APP Semarang untuk menentukan pemenang tender proyek.

\section{METODE}

Metode penelitian pada sistem ini adalah metode Software Development Life Cycle (SDLC) dengan model Waterfall. Model waterfall adalah model klasik yang bersifat sistematis, berurutan dalam membangun software.

Waterfall adalah suatu metodologi pengembangan perangkat lunak yang mengusulkan pendekatan kepada perangkat lunak sistematik dan sekuensial yang mulai pada tingkat kemajuan sistem pada seluruh analisis, design, kode, pengujian dan pemeliharaan.

Tahapan-tahapan dari metode waterfall adalah sebagai berikut:

a. Analisa kebutuhan

Pada tahap ini dilakukan analisis terhadap kebutuhan tender proyek PT. PLN (Persero) APP Semarang.

b. Desain sistem

Pada tahap ini dilakukan desain tampilan sistem, seperti desain tata letak (layout), membuat favicon, membuat slide gambar, membuat menu, dan sebagainya.

c. Penulisan kode program

Pada tahap ini dilakukan konversi dari desain sistem kedalam bahasa pemrograman untuk mendapatkan interface sistem yang sesuai dan kode program untuk membuat sistem pendukung keputusan berdasarkan perhitungan BCR.

d. Pengujian program

Pada tahap ini dilakukan pengujian sistem apakah sistem pendukung keputusan tender proyek sudah berjalan dengan baik atau masih terdapat kesalahan. Jika masih ditemukan kesalahan, maka dilakukan evaluasi dan perbaikan sistem. 
e. Penerapan program dan pemeliharaan

Tahap ini merupakan tahap terakhir dalam model waterfall. Sistem pendukung keputusan tender proyek yang sudah jadi dijalankan serta dilakukan pemeliharaan.

Pemeliharaan termasuk dalam memperbaiki kesalahan yang tidak ditemukan pada langkah sebelumnya.

\section{HASIL DAN PEMBAHASAN}

\section{a. Database Sistem}

Pembuatan sistem pendukung keputusan ini dibuat menggunakan PHP dan MySQL. PHP adalah bahasa serverside-scripting yang menyatu dengan HTML untuk membuat halaman web yang dinamis. (Arief, 2011)

MySQL adalah salah satu jenis database server yang sangat terkenal dan banyak digunakan untuk membangun aplikasi web yang menggunakan database sebagai sumber dan pengolahan datanya. (Saputro dkk, 2008)

Pembuatan database sistem ini terdiri dari 11 tabel yaitu administrasi, berita, evaluasi, harga, kualifikasi, paket, pemenang, perusahaan, peserta, teknis, dan user. Database sistem ditunjukkan pada gambar 1.

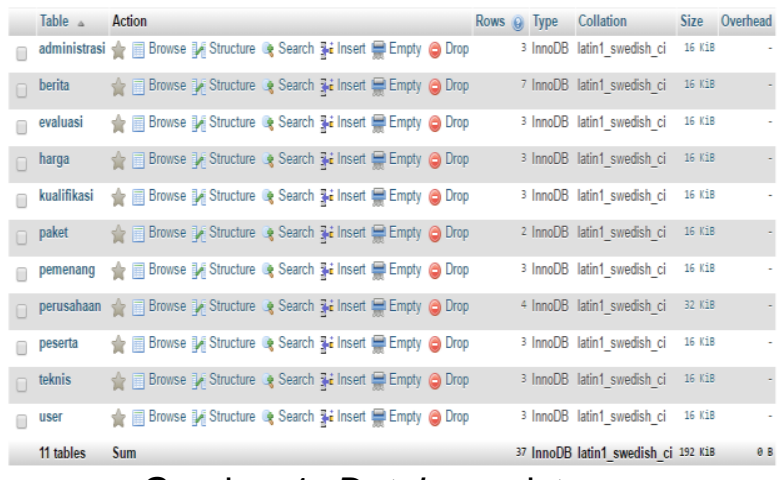

Gambar 1. Database sistem

\section{b. Otentikasi dan Otorisasi Sistem}

Otentikasi adalah proses dalam rangka validasi user pada saat memasuki sistem. Otentikasi pada sistem ini yaitu berupa proses login. Sistem ini memiliki 3 level user yaitu admin, panitia, dan perusahaan. Panitia hanya dapat ditambahkan oleh admin sedangkan perusahaan yang belum memiliki akun dapat mendaftar sebagai peserta tender sebelum melakukan login. Tampilan halaman login ditunjukkan pada gambar 2 .

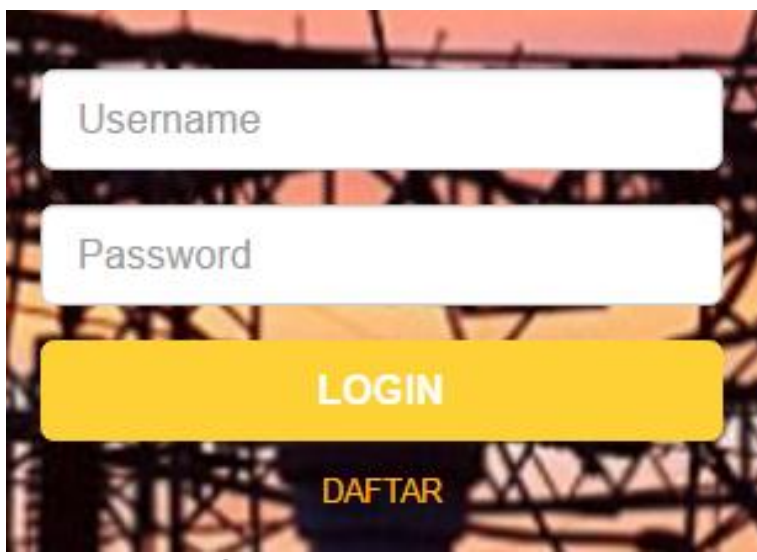

Gambar 2. Halaman login

Setelah user masuk ke dalam sistem dengan menginputkan username dan password, maka sistem akan mengecek kesesuaian username dan password tersebut. Jika username dan password tidak sesuai, maka akan muncul notifikasi username atau password salah. Sebaliknya jika username dan password sesuai, maka proses selanjutnya yaitu proses otorisasi.

Otorisasi merupakan proses pemberian hak-hak akses menu kepada user. Otorisasi ini di set up oleh admin sebagai pemegang hak tertinggi. User yang berhasil melakukan login dapat mengakses menu sesuai dengan hak aksesnya. Otorisasi sistem ini sangat diperlukan agar user yang tidak memiliki wewenang lebih tidak dapat mengakses sistem secara menyeluruh/ Full Acces System.

\section{c. Input Dokumen Tender}

Setelah proses otentikasi dan otorisasi berjalan dengan baik, proses selanjutnya yaitu membuat input dokumen tender. Pada sistem ini, perusahaan yang mendaftar sebagai peserta tender wajib mengisi dokumen-dokumen tender yang terdiri dari kualifikasi, administrasi, teknis, dan harga.

Pada sistem ini, masing-masing kriteria kualifikasi, administrasi, dan teknis memiliki lima subkriteria. Sedangkan kriteria harga hanya memiliki satu 
subkriteria. Selain itu, peserta tender juga harus menginputkan harga penawaran. Pada dasarnya perusahaan penyelenggara tender telah memberikan Harga Perkiraan Sendiri (HPS) yang telah diinformasikan pada paket tender tersebut. Peserta tender yang memiliki harga penawaran lebih rendah dari Harga Perkiraan Sendiri (HPS) akan memberikan nilai lebih bagi peserta tender tersebut. Format dokumen tender yang diinputkan yaitu pdf kecuali input harga penawaran yaitu berupa format angka dalam rupiah. Input dokumen tender ditunjukkan pada gambar 3 .

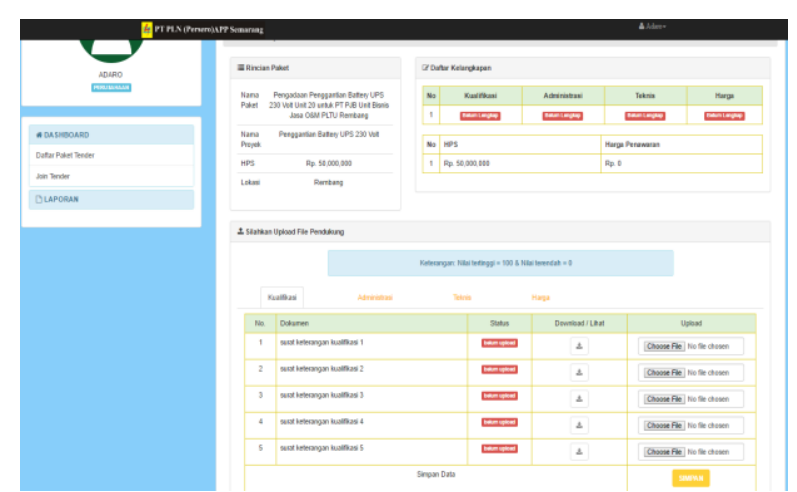

Gambar 3. Input dokumen tender

Setelah masing-masing subkriteria tersebut diinputkan, maka sistem akan mengecek kelengkapan dokumen. Jika dokumen sudah diinputkan dan disimpan, maka sistem akan melakukan pengecekan data dan memberikan notifikasi kelengkapan data.

\section{d. Input Penilaian dan Perhitungan BCR}

Input penilaian dilakukan oleh panitia tender. Sebelum melakukan input penilaian, sistem akan mengecek validasi dokumen. Validasi oleh peserta tender merupakan hal yang penting dalam sistem ini karena panitia tidak dapat melakukan penilaian terhadap dokumen tender yang belum divalidasi oleh peserta tender.

Panitia dapat melakukan penilaian dokumen kualifikasi, administrasi, dan teknis sedangkan penilaian harga dilakukan secara otomatis oleh sistem. Input penilaian berupa pembobotan angka satu sampai lima. Pada kriteria kualifikasi, administrasi, dan teknis memiliki lima subkriteria. Jika jumlah kelima nilai subkriteria kurang dari 15, maka dokumen tersebut dinyatakan tidak lulus. Sedangkan pada kriteria harga memiliki satu subkriteria. Jika nilai subkriteria harga kurang dari 3, maka dokumen tersebut dinyatakan tidak lulus. Gambar 4 merupakan salah satu contoh input penilaian.

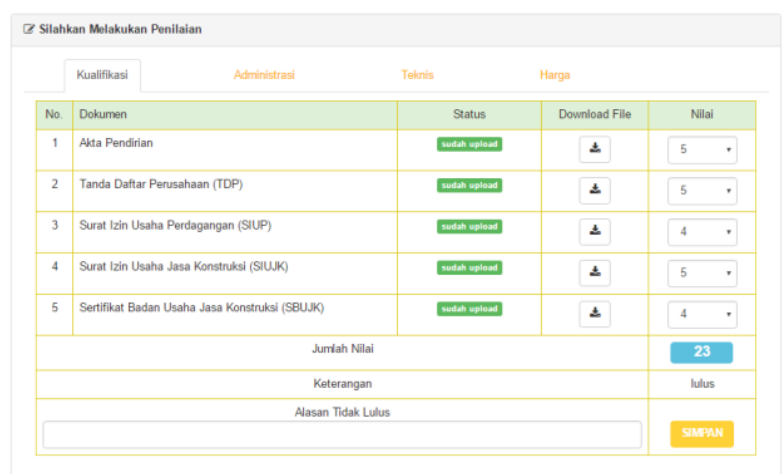

Gambar 4. Input penilaian

Setelah seluruh dokumen sudah dinilai oleh panitia tender, selanjutnya yaitu perhitungan BCR. Penerapan perhitungan BCR ke dalam nilai sekarang (present value), yaitu:

$$
\text { BCR }=\frac{\text { PV Benefits }}{\text { PV Costs }}
$$

Pada sistem ini dilakukan pembobotan dengan ketentuan sebagai berikut:

$$
\begin{aligned}
& \text { Benefits }=\frac{\text { HPS X Jumlah Bobot }}{48} \\
& B C R=\frac{\text { Benefits }}{\text { HPS }}
\end{aligned}
$$

a. Jika nilai $B C R<1$ maka manfaat yang ditimbulkan proyek lebih kecil dari biaya yang diperlukan secara ekonomi, proyek tersebut tidak layak untuk dijalankan.

b. Jika nilai $\mathrm{BCR}=1$ maka manfaat yang ditimbulkan proyek sama dengan biaya yang diperlukan secara ekonomi, proyek tersebut layak untuk dijalankan.

c. Jika nilai $B C R>1$ maka manfaat yang ditimbulkan proyek lebih besar dari biaya yang diperlukan secara ekonomi, proyek tersebut layak untuk dijalankan. 
Source code perhitungan BCR ditunjukkan pada tabel 1.

\section{Tabel 1. Source code perhitungan BCR}

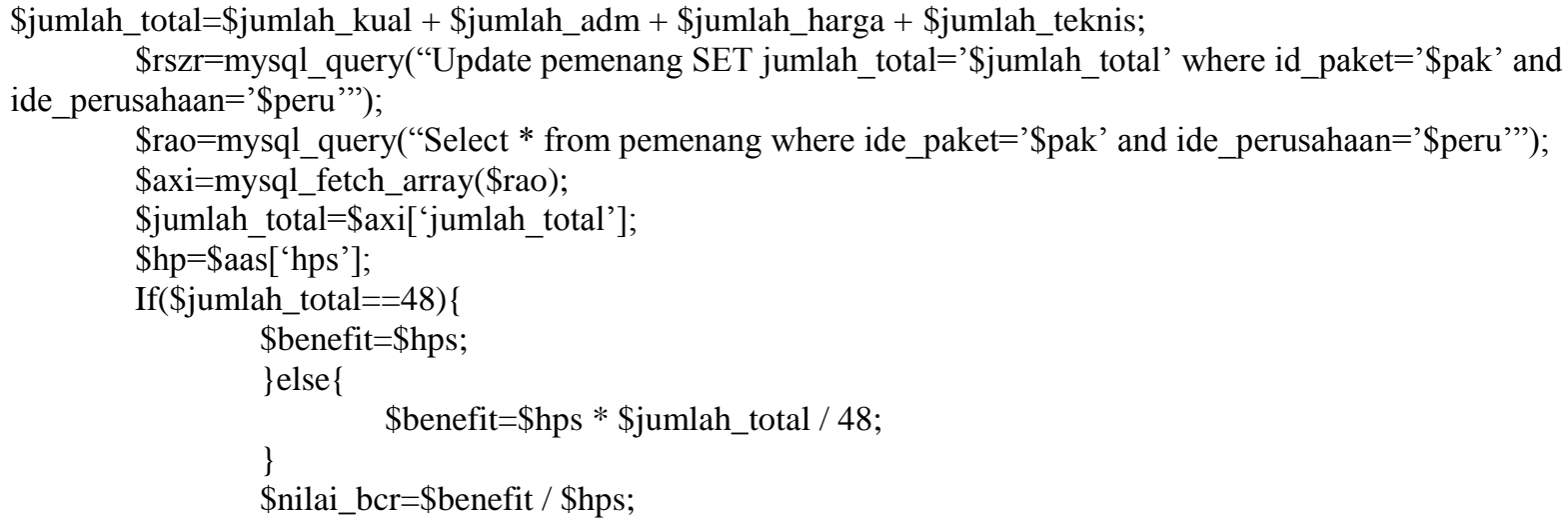

Setelah melalui tahap penilaian, maka langkah selanjutnya yaitu melakukan validasi pemenang tender. Panitia dapat memutuskan pemenang tender proyek berdasarkan beberapa aspek penilaian menggunakan metode BCR dengan harga penawaran, manfaat, dan biaya yang sesuai dengan kebutuhan perusahaan sehingga proyek tersebut layak untuk dijalankan. Data pemenang tender ditunjukkan pada gambar 6.

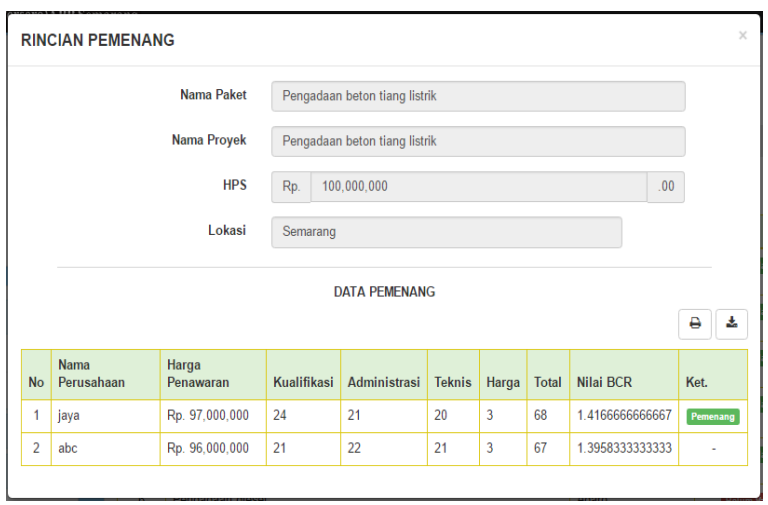

Gambar 6. Data pemenang tender

\section{SIMPULAN}

Cara pembuatan sistem pendukung keputusan tender proyek menggunakan metode Benefit Cost Ratio (BCR) pada PT. PLN (Persero) APP Semarang dengan PHP dan MySQL langkah pertama yang dilakukan yaitu membuat database sistem secara lokal. Langkah kedua yaitu membuat otentikasi dan otorisasi sistem. Sistem ini memiliki 3 level user yaitu admin, panitia, dan perusahaan. User yang berhasil melakukan login akan mendapatkan otorisasi sehingga masing-masing user memiliki hak ases yang berbeda. Langkah ketiga yaitu membuat input dokumen tender yang meliputi dokumen kualifikasi, administrasi, teknis, dan harga oleh perusahaan yang menjadi peserta tender. Setelah seluruh dokumen diinputkan, peserta tender harus melakukan validasi karena dokumen yang belum divalidasi tidak dapat dinilai oleh panitia tender. Langkah terakhir yaitu membuat input penilaian dan perhitungan BCR. Setelah proses input penilaian selesai dan divalidasi oleh panitia, maka didapatkan pemenang tender proyek sesuai perhitungan Benefit Cost Ratio (BCR).

\section{DAFTAR PUSTAKA}

Arief, MR. 2011. Pemrograman Web Dinamis Menggunakan PHP dan MySQL. ANDI, Yogyakarta.

Giatman, M. 2006. Ekonomi Teknik. PT. Raja Grafindo Persada, Jakarta.

Kusrini. 2007. Konsep dan Aplikasi Sistem Pendukung Keputusan. ANDI, Yogyakarta.

Pressman, RS. 2010. Software Engineering: a practitioner's approach. McGraw-Hill, New York. 
Saputro, Haris

dan

Sugiri. 2008. Pengelolaan Database

MySQL dengan PHPMyAdmin. Graha IImu, Yogjakarta.

Yakub. 2012. Pengantar Sistem Informasi.

Graha IImu, Yogyakarta. 